\title{
PENGARUH LAMA WAKTU PEMASAKAN DAN KONSENTRASI RAGI TERHADAP KARAKTERISTIK ORGANOLEPTIK DAN KADAR ALKOHOL TAPE UBI UNGU
}

\section{The Effect of Cooking Time and Yeast Concentration on Quality of Purple Sweet Potato Tape}

\author{
Deviko Mardyansah*, Ainin Nadiroh, Yuni Rohmawati, Lintang Aurelia Syahri \\ Jurusan Biologi, FMIPA Universitas Negeri Surabaya \\ Jalan Ketintang Gedung C3 Lt.2, Surabaya 60231 \\ *Penulis korespondensi, Email: mardyansah.deviko@gmail.com
}

\begin{abstract}
ABSTRAK
Ubi ungu (Ipomoea batatas var Ayamurasaki) termasuk dalam komoditas pertanian yang jumlah produksinya melimpah di Indonesia. Tujuan penelitian adalah mengetahui pengaruh lama waktu pemasakan ubi dan konsentrasi ragi tape yang optimal untuk mendapatkan tape ubi jalar ungu dengan kualitas terbaik. Metode penelitiannya eksperimental dengan sembilan perlakuan dan tiga ulangan. Tahapan penelitian meliputi persiapan alat dan bahan, pembuatan tape ubi ungu, setelah itu tape diuji organoleptik dan kadar alkoholnya, serta analisis data. Hasil menunjukkan bahwa lama waktu pemasakan yang terbaik adalah 35 menit dan konsentrasi ragi yang terbaik adalah $2 \%$. Kesimpulannya lama waktu pemasakan dan konsentrasi ragi terbaik untuk kualitas tape ubi ungu adalah 35 menit dengan konsentrasi ragi sebesar $2 \%$.
\end{abstract}

Kata kunci: Konsentrasi Ragi, Lama Pemasakan, Tape, Ubi Ungu

\section{ABSTRACT}

Purple sweet potato (Ipomoea batatas var Ayamurasaki) is included in agricultural commodities with abundant production in Indonesia. The purpose of this study was to determine the effect of the length of time of cooking and optimal yeast tape concentration to get the best quality purple sweet potato tape. The method that used was experimental with nine treatments and three replications. The stages of the research included preparation of tools and materials, making purple yam tape, after that the tape was tested for organoleptic and alcohol content, and then data analysis. The results showed that the best cooking time was 35 minutes and the best yeast concentration was $2 \%$. In conclusion, the best cooking time and yeast concentration for quality purple yam tape were 35 minutes with yeast concentration of $2 \%$.

Keywords: Cooking Time, Purple Sweet Potato, Tape, Yeast Concentration

\section{PENDAHULUAN}

Tape adalah makanan hasil proses fermentasi bahan pangan dengan kandungan pati yang cukup tinggi seperti pada singkong maupun ketan. Beberapa sebutan tape, antara lain peyeum, tape pulut, tape tela, dan lao-chao (Hidayat et al., 2006). Selain singkong dan ketan, tape juga dapat dibuat dari ubi jalar, karena ubi jalar memiliki kalori dan kandungan karbohidrat yang tinggi.

Ubi jalar ungu (Ipomoea batatas L.) telah menyebar hampir di seluruh wilayah Indonesia sejak 1960-an (Rukmana, 2001). Ubi ungu (Ipomoea batatas L.) termasuk dalam komoditas pertanian dengan jumlah produksinya yang melimpah di Indonesia. Menurut 
Badan Pusat Statistik tahun 2015, Indonesia dapat memproduksi ubi ungu sekitar 2.438.076 ton per tahunnya.

Kandungan ubi ungu meliputi serat pangan alami yang tinggi, kadar indeks glisemik rendah, prebiotik, dan oligosakarida. Selain itu, ubi ungu juga mengandung $\mathrm{K}, \mathrm{Cu}, \mathrm{Mg}, \mathrm{Zn}$, dengan rata-rata 20\%. Menurut Handayani (2013), Ubi ungu kaya akan serat kasar, lemak, mineral, vitamin, dan protein. Jika dibandingkan ubi jalar varietas lainnya, kandungan nutrisi ubi ungu lebih tinggi. Kandungan nutrisi ubi ungu ini sesuai untuk kebutuhan pertumbuhan mikroba selama proses fermentasi (Suda et al., 2003). Selain kaya akan nutrisi, pigmen antosianin yang menyebabkan warna ungu pekat pada kulit maupun daging umbi juga memiliki manfaat sebagai antioksidan, mencegah terjadinya gangguan fungsi pada hepar, dan antihipertensi.

Tape digolongkan sebagai sumber probiotik bagi tubuh karena dapat membantu proses pencernaan agar berfungsi dengan baik (Muhidin et al., 2001). Pembuatan tape melalui proses fermentasi perlu ditambahkan dengan ragi tape. Menurut Merican and Queeland (2004), ragi tape adalah starter kering yang terbuat dari campuran tepung beras, ramuan bumbu, air dan ekstrak gula tebu. Keberhasilan fermentasi dipengaruhi oleh jumlah ragi, jenis substrat, suhu, udara (oksigen).

Penelitian yang telah dilakukan oleh Adhitya dkk. (2012) dan Abdillah dan Widyawati (2014), perlakuan lama waktu pemasakan ubi yang berbeda 25 menit, 30 menit, dan 35 menit menunjukkan tape ubi jalar ungu dengan hasil terbaik adalah pada waktu pemasakan 30 menit. Sedangkan perlakuan tradisionalnya dengan konsentrasi berbeda $1 \%$, $2 \%$, dan $3 \%$. Hasil penelitiannya menunjukkan bahwa perlakuan yang dapat memberikan pengaruh paling optimal terhadap kadar karbohidrat dan kadar protein pada kualitas tape biji gandum adalah konsentrasi ragi $1 \%$.

Berdasarkan permasalahan tersebut, maka tujuan dari penelitian ini adalah mengetahui pengaruh lama waktu pemasakan ubi dan konsentrasi ragi tape yang optimal untuk mendapatkan tape ubi ungu dengan kadar alkohol dan karakteristik fisik terbaik.

\section{BAHAN DAN METODE}

\section{Bahan}

Penilitian ini menggunakan bahan yaitu ubi ungu (Ipomoea batatas) yang diperoleh dari pasar DTC, Surabaya. Bahan pendukung seperti ragi tape Na Kok Liong (NKL) yang diperoleh di pasar Desa Metatu Gresik, daun pisang diperoleh di Desa Pundutrate Gresik, dan air.

\section{Alat}

Penelitian ini membutuhkan beberapa peralatan yakni timbangan, baskom, dandang, sendok, kompor, pisau. Sedangkan alat yang dibutuhkan dalam analisis adalah alkohol meter ALLA dan alat tulis.

\section{Tahapan Penelitian}

\section{Pembuatan Tape Ubi Ungu}

Ubi ungu disortir dan dikupas kulitnya, kemudian dicuci dengan air mengalir dan ditiriskan. Penelitian yang telah dilakukan oleh Adhitya dkk. (2012) dan Abdillah dan Widyawati (2014). Ubi ungu dipotong-potong sehingga ukurannya menjadi lebih kecil. Ubi ungu ditimbang $100 \mathrm{~g}$ untuk masing-masing sembilan perlakuan kemudian dikukus dengan lama waktu sesuai perlakuan (25 menit, 30 menit, 35 menit) dan didinginkan. Ubi ungu diinokulasi masing-masing konsentrasi ragi sebesar 1,0\%, 2,0\%, dan 3,0\% dari berat bahan hingga merata. Setelah diberi ragi, ubi difermentasi pada suhu kamar $\left(28-30^{\circ} \mathrm{C}\right)$ selama 3 hari.

\section{Uji Organoleptik}

Uji ini dilakukan untuk mengetahui kecocokan selera masyarakat terhadap tape ubi ungu. Terdapat 3 sampel/perbandingan dengan masing-masing 50 gram. Terdapat 9 
perbandingan berbeda, sehingga ada sekitar 27 sampel yang dibagikan ke 25 responden. Responden juga akan mengisi questioner berisi tentang penilaian produk tape ditinjau dari: aroma, warna, tekstur, dan rasa. Skala uji organoleptik yang dipakai adalah 3 skala yaitu 3, 2 dan 1. Menurut Sulistiyo (2006), skala hedonik dapat direntangkan sesuai dengan kehendak peneliti, juga dapat diubah menjadi skala numerik dengan angka mutu menurut tingkat kesukaan. Skor untuk uji kualitas terhadap warna adalah 3 (Ungu), 2 (Ungu kemerahan), 1 (Ungu muda). Skor uji kualitas untuk kriteria tekstur adalah 3 (lembut), 2 (kurang lembut), 1 (keras). Skor uji kualitas untuk kriteria rasa adalah 3 (Manis), 2 (Kurang manis), 1 (asam). Skor uji kualitas untuk kriteria aroma adalah 3 (kurang beralkohol), 2 (sedikit beralkohol), 1 (sangat beralkohol).

\section{Uji Kadar Alkohol}

Uji kadar alkohol menggunakan alkohol meter berdasarkan metode Prastujati dkk, (2018). Sampel dimasukkan ke dalam gelas ukur kapasitas $100 \mathrm{ml}$ lalu didinginkan pada suhu $20^{\circ} \mathrm{C}$. Alkoholmeter dimasukan ke dalam gelas ukur lalu dicatat hasil pengukurannya.

\section{Desain Penelitian}

Pertimbangan dalam menentukan lama waktu pemasakan adalah dengan hasil penelitian dari Adhitya dkk. (2012) yang menggunakan ubi jalar ungu dan memperoleh hasil lama pemasakan yang paling optimum pada lama waktu 30 menit lalu dilakukan modifikasi sekitar rentan waktu tersebut pada penelitian ini.

Tabel 1. Rancangan Percobaan Tape Ungu

\begin{tabular}{cccc}
\hline & \multicolumn{3}{c}{ Konsentrasi Ragi (\%) } \\
\hline $\begin{array}{c}\text { Lama Waktu } \\
\text { Pemasakan (menit) }\end{array}$ & $\mathbf{1 . 0}$ & $\mathbf{2 . 0}$ & $\mathbf{3 . 0}$ \\
\hline \multirow{2}{*}{25} & $\mathrm{P}_{11}$ & $\mathrm{P}_{41}$ & $\mathrm{P}_{71}$ \\
& $\mathrm{P}_{12}$ & $\mathrm{P}_{42}$ & $\mathrm{P}_{72}$ \\
& $\mathrm{P}_{13}$ & $\mathrm{P}_{43}$ & $\mathrm{P}_{73}$ \\
30 & $\mathrm{P}_{21}$ & $\mathrm{P}_{51}$ & $\mathrm{P}_{81}$ \\
& $\mathrm{P}_{22}$ & $\mathrm{P}_{52}$ & $\mathrm{P}_{82}$ \\
& $\mathrm{P}_{23}$ & $\mathrm{P}_{53}$ & $\mathrm{P}_{83}$ \\
35 & $\mathrm{P}_{31}$ & $\mathrm{P}_{61}$ & $\mathrm{P}_{92}$ \\
& $\mathrm{P}_{32}$ & $\mathrm{P}_{62}$ & $\mathrm{P}_{93}$ \\
\hline
\end{tabular}

\section{Metode}

Metode penelitiannya yakni eksperimental menggunakan Rancangan Acak Lengkap (RAK) dengan dua faktor terdiri atas faktor I yaitu dosis ragi $(1 \%, 2 \%, 3 \%)$ dan faktor II lama waktu pemasakan (25 menit, 30 menit, 35 menit) untuk $100 \mathrm{~g}$ ubi ungu. Ada sembilan perlakuan yakni $P_{1}, P_{2}, P_{3}, P_{4}, P_{5}, P_{6}, P_{7}, P_{8}, P_{9}$. Pengujian yang dilakukan adalah uji organoleptik yaitu rasa, aroma, warna, dan rasa. Uji kimia juga dilakukan yaitu uji kadar alkohol.

\section{Prosedur Analisis}

Analisis pada tape ubi ungu meliputi analisis kimia meliputi kadar alkohol dengan alkohol meter ALLA, analisis organoleptik meliputi analisis kesukaan terhadap aroma, rasa, warna, dan tekstur tape ubi ungu. 
Pengaruh Lama Waktu Pemasakan dan Konsentrasi Ragi - Mardyansah, dkk Jurnal Pangan dan Agroindustri Vol.8 No.2: 104-110, April 2020

HASIL DAN PEMBAHASAN

\section{Karakteristik Organoleptik}

Tabel 2. Hasil Rerata Uji Organoleptik Pada Tape Ubi Ungu Perlakuan Konsentrasi Ragi dan Lama Waktu Pemasakan

\begin{tabular}{lccccccccc}
\hline \multirow{2}{*}{ Uji } & \multicolumn{10}{c}{ Perlakuan } \\
\cline { 2 - 10 } & $\mathrm{P}_{1}$ & $\mathrm{P}_{2}$ & $\mathrm{P}_{3}$ & $\mathrm{P}_{4}$ & $\mathrm{P}_{5}$ & $\mathrm{P}_{6}$ & $\mathrm{P}_{7}$ & $\mathrm{P}_{8}$ & $\mathrm{P}_{9}$ \\
\hline Aroma Tape Ubi Ungu & 1.26 & 1.95 & 2.21 & 1.74 & 1.62 & 2.00 & 2.15 & 1.74 & 1.82 \\
Warna Tape Ubi Ungu & 2.62 & 2.13 & 2.36 & 2.44 & 1.67 & 1.85 & 2.59 & 2.05 & 1.82 \\
Tekstur Tape Ubi Ungu & 1.77 & 2.38 & 2.54 & 2.21 & 2.59 & 2.21 & 2.18 & 2.26 & 2.31 \\
Rasa Tape Ubi Ungu & 1.41 & 1.33 & 1.95 & 1.44 & 1.79 & 2.05 & 1.82 & 1.82 & 1.95 \\
\hline
\end{tabular}

Pada tape ubi ungu dilakukan uji organoleptik dengan menggunakan 3 skala penilaian terdiri dari aroma, tekstur, warna, dan rasa. Sampel tape ubi ungu terdiri dari 2 komponen yaitu ubi ungu dan ragi tape. Satu sampel tape ubi ungu memiliki massa yaitu 100 gram. Jumlah panelis yang terlibat dalam uji organoleptik yaitu 25 panelis dengan kriteria dari kalangan akademis. Panelis diberikan instruksi untuk menuliskan penilaian dan tanggapan mengenai aroma, tekstur, warna serta rasa dari kesembilan sampel tape ubi ungu dalam lembar form dengan cara menuliskan nomor terhadap kesan sesuai yang dirasakan. Hasil rata-rata paling tinggi dalam segi aroma, tekstur, warna maupun rasa terlihat secara berturut-turut pada sampel $P_{6}, P_{1}, P_{5}$, dan $P_{6}$. Sampel $P_{1}$ terdiri dari 25 menit pemasakan dengan $1 \%$ ragi tape, sampel $\mathrm{P}_{5}$ terdiri dari 30 menit pemasakan dengan $2 \%$ ragi tape, dan sampel $\mathrm{P}_{6}$ terdiri dari 30 menit pemasakan dengan $3 \%$ ragi tape.

\section{a. Aroma}

Aroma tape ubi ungu pada Tabel 2 menunjukkan nilai terendah $P_{1}(1.26)$ dan nilai tertinggi $P_{6}(2.00)$ dengan kriteria kurang beralkohol. Aroma tape ubi ungu masih khas ubi ungu dengan sedikit berbau alkohol dikarenakan proses fermentasi pada pembuatan tape ubi ungu dengan hanya 3 hari serta konsentrasi ragi tape kurang merata sehingga fermentasi kurang berjalan dengan baik. Aroma pada tape tersebut dikarenakan terdapat senyawa volatil dari tape yang bisa dideteksi oleh indera pembau (Rachmawati, 2001). Kadar alkohol pada tape serta tingkat keasamannya akan semakin meningkat akan menjadikan semakin kuatnya aroma pada tape ubi ungu jika proses fermentasi yang terjadi semakin lama (Setyohadi, 2006). Menurut Winarno dan Fardiaz, (1990) tajamnya aroma khas tape dipengaruhi oleh komponen volatil yang menguap dan diterima oleh indra sebagai aroma khas dari tape.

\section{b. Warna}

Dari data yang diperoleh, nilai rata-rata terendah untuk warna sebesar $1.67\left(\mathrm{P}_{5}\right)$ sedangkan nilai rata-rata tertinggi sebesar $2.62\left(\mathrm{P}_{1}\right)$. Hal ini disebabkan karena pada warna ungu pada tape ubi ungu bercampur warna putih ragi tape yang digunakan dalam proses fermentasi. Sehingga kebanyakan panelis yang sudah terbiasa dengan warna tape yang putih kekuningan menjadikan warna tape ubi ungu sebagai hal yang masih baru. Menurut Kusmawati dkk. (2000) warna produk dari hasil fermentasi tidak beda jauh dari warna awalnya.

\section{c. Tekstur}

Tekstur tape ubi ungu pada Tabel 2 menunjukkan rata-rata berkisar antara 1.77 sampai 2.59 dengan kriteria keras hingga lembut. Nilai terendah diperoleh pada sampel $\mathrm{P}_{1}$ yaitu 1.77 sedangkan nilai tertinggi diperoleh pada sampel $P_{5}$ yaitu 2.59. Evaluasi sensoris pada tekstur uji skor menunjukkan semakin lama waktu pengukusan dan besarnya konsentrasi ragi tape, tekstur yang dihasilkan semakin melunak. Lamanya waktu 
pengukusan bisa berpengaruh dalam hasil tekstur dari ubi ungu yang berubah menjadi mudah hancur serta lunak, sebaliknya pengukusan dalam waktu singkat akan membuat tekstur ubi jalar ungu masih keras (Adhitya dkk, 2012).

\section{d. Rasa}

Rasa tape ubi ungu pada Tabel 2 menunjukkan rata-rata berkisar antara 1.33 sampai 2.05 dengan asam hingga manis. Nilai terendah diperoleh pada sampel $P_{2}$ yaitu 1.33 sedangkan nilai tertinggi diperoleh sampel $P_{6}$ yaitu 2.05. Rasa tape ubi ungu dipengaruhi dari lamanya waktu fermentasi, karena waktu fermentasi yang semakin lama dapat meningkatkan derajat keasaman dan kadar alkohol. Sehingga dapat berpengaruh terhadap rasa dari tape ubi ungu. Hal tersebut sesuai dengan Wahyuni dan Astawan (1991) yang menyatakan bahwa lama fermentasi terhadap tape akan mempengaruhi rasa dan sesuainya waktu dapat mengjadikan tape dengan rasa yang manis, rasa masam dan terdapat aroma alkohol.

\section{Karakteristik Kimia}

Berdasarkan Tabel 3. didapatkan hasil yaitu perlakuan pemberian konsentrasi ragi yang berbeda $\mathrm{F}$ hitung (42.42) > F5\%(6.94) signifikan, perlakuan lama waktu pemasakan $\mathrm{F}$ hitung $(0.29)<\mathrm{F} 5 \%(3.89)$ tidak signifikan terhadap kadar alkohol tape ubi ungu, dan perlakuan kombinasi konsentrasi ragi dan lama waktu pemasakan $F$ hitung $(1.31)<$ F5\%(3.26) juga tidak signifikan terhadap kadar alkohol tape ubi ungu.

Tabel 3. Pengaruh Konsentrasi Ragi dan Lama Waktu Pemasakan terhadap Rerata Kadar Alkohol Tape Ubi Ungu

\begin{tabular}{ccc}
\hline $\begin{array}{c}\text { Konsentrasi Ragi } \\
(\%)\end{array}$ & $\begin{array}{c}\text { Lama Waktu } \\
\text { Pemasakan (menit) }\end{array}$ & Kadar Alkohol \\
\hline \multirow{2}{*}{1} & 25 & 4.30 \\
& 30 & 5.00 \\
2 & 35 & 6.00 \\
& 25 & 14.67 \\
& 30 & 13.67 \\
3 & 35 & 15.33 \\
& 25 & 13.33 \\
& 30 & 16.00 \\
& 35 & 9.67 \\
\hline
\end{tabular}

Berdasarkan hasil uji BNT 5\% didapatkan hasil yaitu pengaruh pemberian konsentrasi ragi sebesar $2 \%$ menghasilkan kadar alkohol terbaik dibandingkan konsentrasi yang lain. Alkohol dalam tape ubi ungu dikarenakan adanya proses yang terjadi yaitu fermentasi. Fermentasi dari tape ubi ungu disebabkan oleh adanya pengaruh pemberian ragi tape. Pada ragi tape terdapat mikrobia seperti kapang, khamir, dan bakteri (Barus, 2013). Adanya mikroba tersebut memicu terjadinya proses dalam fermentasi yang dimulai adanya hidrolisis pati dengan bantuan enzim amilase dan didapatkan hasil akhir berupa alkohol (Finalika dan Widjanarko 2015). Pernyataan tersebut juga diperkuat oleh pernyataan Unika (2015) bahwa proses fermentasi yang semakin lama akan menjadikan semakin tinggi jumlah mikroorganisme dalam proses perombakan pati menjadi glukosa sampai menghasilkan alkohol, sehingga kadarnya menjadi tinggi. Alkohol yang dihasilkan akan mempengaruhi karakteristik tape ubi ungu tersebut. Lama waktu dalam proses fermentasi juga akan berpengaruh pada kadar gula pereduksi yang berbeda pada tiap harinya (Suliantri dan Winiarti, 1991). 


\section{SIMPULAN}

Berdasarkan penelitian yang telah dilakukan didapatkan kesimpulan bahwa perlakuan pemberian konsentrasi ragi yang berbeda Fhitung (42.42) $>\mathrm{F} 5 \%(6.94)$ signifikan, perlakuan lama waktu pemasakan Fhitung (0.29) < F5\%(3.89) tidak signifikan, dan perlakuan kombinasi konsentrasi ragi dan lama waktu pemasakan Fhitung (1.31) < F5\%(3.26) tidak signifikan. Hasil dari uji BNT yaitu pengaruh pemberian konsentrasi ragi sebesar $2 \%$ dengan lama waktu pemasakan 35 menit menghasilkan kadar alkohol terbaik dibandingkan konsentrasi yang lain.

\section{DAFTAR PUSTAKA}

Abdillah, J., dan Widyawati, N. 2014. Pengaruh Dosis Ragi Dan Penambahan Gula Terhadap Kualitas Gizi Dan Organoleptik Tape Biji Gandum. Agric, 26(1), 75-84.

Adhitya, S.G., Yusa N.M., dan Yusasrini, N.L.A. 2012. Pengaruh Waktu Pengukusan dan Fermentasi Terhadap Karakteristik Tape Ubi Jalar Ungu (Ipomoea batatas var. Ayamurasaki). Jurnal IImu dan Teknologi Pangan. 1(1): 1-9.

Badan Pusat Statistik. 2015. Data Produksi Padi, Jagung, dan Kedelai Provinsi Lampung tahun 2014. Berita Resmi Statistik. Lampung.

Barus T. 2013. Diversity of amylase producing Bacillus spp. from tape (fermented cassava. Hayati Journal of Bioscience. 20(2): 94-98.

Finalika E. dan Widjanarko, S.B. 2015. Penetuan Nilai Maksimum Respon Rendemen dan Gula Reduksi Brem Padat Tape Ubi Kayu (Manihot esculenta). Jurnal Pangan dan Agroindustri. 3 (2): $670-680$.

Handayani, Eny. 2013. Uji Kadar Protein dan Uji Organoleptik Tape Ubi Ungu (Ipomoea batatas L) Melalui Fermentasi Dengan Dosis Ragi Yang Berbeda dan Penambahan Sari Kulit Buah Nanas (Ananas comosus). Skripsi. Universitas Muhammadiyah Surakarta.

Hidayat, N., M. C. Padaga dan S. Suhartini. 2006. Mikrobiologi Industri. Penerbit Andi. Yogyakarta.

Kusumawati, Aan, Ujang, H., dan Evi, E. 2000. Dasar-dasar Pengolahan Hasil Pertanian. Central Grafika. Jakarta.

Merican Z. and Queeland, Y. 2004. Tape Processing In Malaysia: A Technology In Transition. Industrialization of Indigeneous Fermented Foods, pp. 247-270.

Muhidin N.H., N. Juli, dan I.N.P. Aryantha. 2001. Peningkatan Kandungan Protein Kulit Umbi Ubi Kayu Melalui Proses Fermentasi. Jurnal Matematika dan Sains 6 (1).

Prastujati, A. U., Hilmi, M., \& Khirzin, M. H. (2018). Pengaruh konsentrasi starter terhadap kadar alkohol, $\mathrm{pH}$, dan total asam tertitrasi (TAT) whey kefir (the effect of starter concentration on alcohol, $\mathrm{pH}$, and total titrated acids (TTA) in whey kefir). Jurnal IImu Peternakan Terapan, 1(2).

Rachmawati, N. 2001. Pengaruh Penambahan Tape dan Tepung Tape Ubi Kayu (Manihot Esculenta Crantz) Terhadap Mutu Organoleptik dan Umur Simpan Cake Tape Sebagai Salah Satu Untuk Memanfaatkan dan Meningkatkan Nilai Produk Tradisional. Bogor: Skripsi Fakultas Teknologi Pertanian IPB.

Rukmana, Rahmat. 2001. Ubi Jalar : Budidaya dan Analisis Usaha. Penerbit Kanisius. Yogyakarta.

Setyohadi. 2006. Proses Mikrobiologi Pangan (proses kerusakan dan pengolahan). USU Press. Medan.

Suda, I., T. Oki, M. Masuda, M. Kobayashi, Y. Nishiba, and S. Furuta. 2003. Physiological Functionality of Purple-fleshed Sweet Potatoes Containing Anthocyanins and Their Utilization in Foods. JARQ 37(3): 167-173.

Suliantri dan Winiarti. 1991. Teknologi Fermentasi Biji-bijian dan Umbi-umbian. Departemen $P$ dan K Direktorat Jendral Pendidikan Tinggi Pusat Universitas Pangan dan Gizi IPB. Bogor. 
Pengaruh Lama Waktu Pemasakan dan Konsentrasi Ragi - Mardyansah, dkk Jurnal Pangan dan Agroindustri Vol.8 No.2: 104-110, April 2020

Sulistiyo, CN. 2006. Pengembangan Brownies Kukus Tepung Ubi Jalar di PT. Fits Mandiri Bogor. Skripsi. Fakultas Teknologi Pertanian. Institut Pertanian Bogor. IPB.

Unika, A. 2015. Pengaruh jumlah ragi dan waktu fermentasi terhadap sifat organoleptik tapai pisang tanduk. E-Journal Boga. 4(1): 192-201.

Wahyuni, A. M dan M. Astawan. 1991. Teknologi Pengolahan Pangan Nabati Tepat Guna. Akademika Presssiado. Bogor.

Winarno dan Fardiaz. 1990. Pengantar Teknologi Pangan. Gramedia. Jakarta. 